\title{
GERAKAN LITERASI SEKOLAH BERBASIS WEST JAVA LEADER' S READING CHALLANGE
}

\author{
Zaenul Slam \\ Universitas Islam Negeri Syarif Hidayatullah Jakarta \\ E-mail: zaenul_slam@yahoo.com
}

Naskah diterima : 31 Januari 2017, direvisi : 20 Februari 2017, disetujui : 20 April 2017

\begin{abstract}
The purpose of this study was to describe the literary movement based West Java School Leader's Reading Challenge (WJLRC) in Junior High School 3 Majalengka. This research is a qualitative research. The technique of collecting data through observation, interviews, and documentation. Subjects were the principal, teachers, students, and parents. The data analysis in research through the three stages of data reduction, data presentation, and conclusion. Test the validity of the data is using triangulation sources. The results of this study show that: The first, the motion read into the daily activities of the entire school community. This is evident from: 1) school regularly conducting reading 15 minutes before the lesson begins; 2) available and utilization of facilities and infrastructure reads like a library, a reading corner and others; 3) increasing the number of visits of students and teachers to the library of school ; 4) Implementation of Readhaton / other mass reading activities periodically. The second, the formation of a community of students read through WJLRC This is evident from: 1) increasing the number of books read and made review by students; 2) increasing the speed reading student participants WJLRC activities; 3) the continuity and sustainability of WJLRC between classes. The third, the publication of writings by students and teachers of literacy. It appears from the evidence of the activities and work the students and teachers of literacy on the website WJLRC. The fourth, the growing support of parents and the community to the school literacy movement. This is evident from: 1) the direct involvement of parents and the community in a variety of school activities literacy movements; 2) increasing the support and concern of parents and the community to the efforts of growing culture in homes and communities; 3) the donation of books to the school from parents and the community.
\end{abstract}

Keywords: The School Literacy Movement, West Java Leader's Reading Challenge Junior High School 3 Majalengka 


\begin{abstract}
Abstrak
Tujuan study ini adalah untuk mendeskripsikan Gerakan Literasi Sekolah berbasis West Java Leader's Reading Challange (WJLRC)di SMP Negeri 3 Majalengka. Penelitian ini merupakan penelitian kualitatif. Teknik pengumpulan data melalui observasi, wawancara, dan dokumentasi. Subjek penelitian adalah kepala sekolah, guru, siswa, dan orang tua. Analisis data dalam penelitian ini melalui tiga tahap yaitu: reduksi data, penyajian data, dan penarikan kesimpulan. Uji keabsahan data menggunakan triangulasi sumber. Hasil penelitian ini menunjukkan bahwa: Pertama, gerakan membaca menjadi aktivitas keseharian seluruh warga sekolah. Hal ini terlihat dari: 1) sekolah secara rutin melaksanakan kegiatan membaca 15 menit sebelum jam pelajaran dimulai;2) tersedia dan dimanfaatkannya sarana dan prasarana membaca seperti perpustakaan, pojok baca dan lain-lain; 3) meningkatnya jumlah kunjungan siswa dan guru ke perpustakaan sekolah; 4) Terlaksananya Readhaton / kegiatan membaca massal lainnya secara periodik. Kedua, terbentuknya komunitas siswa membaca melalui kegiatan WJLRC Hal ini tampak dari: 1) meningkatnya jumlah buku yang dibaca dan dibuat reviunya oleh siswa; 2) meningkatnya kecepatan membaca siswa peserta kegiatan WJLRC; 3) adanya kesinambungan dan keberlanjutan kegiatan WJLRC antar kelas. Ketiga, publikasi tulisan karya literasi siswa dan guru. Hal ini tampak dari adanya bukti aktivitas dan karya literasi siswa serta guru pada website WJLRC. Keempat, meningkatnya dukungan orang tua dan masyarakat terhadap gerakan literasi sekolah. Hal ini tampak dari: 1) adanya keterlibatan langsung orang tua dan masyarakat dalam berbagai kegiatan gerakan literasi sekolah; 2) meningkatnya dukungan dan kepedulian orang tua dan masyarakat terhadap upaya penumbuhan budaya baca di rumah dan lingkungan masyarakat; 3) adanya donasi buku untuk sekolah dari orang tua dan masyarakat.
\end{abstract}

Kata Kunci: Gerakan Literasi Sekolah, West Java Leader's Reading Challange, SMPN 3 Majalengka

Pengutipan: Slam, Zainul. (2017). Gerakan Literasi Sekolah Berbasis West Java Leader's Reading Challange. JMIE: Journal of Madrasah Ibtidaiyah Education, 1(1), 2017, 6080. sd.v1i1.25. 


\section{PENDAHULUAN}

Mengapa diperlukan gerakan literasi sekolah ? Pada abad ke-21 ini, kemampuan berliterasi siswa berkait erat dengan tuntutan keterampilan membaca yang berujung pada kemampuan memahami informasi secara analisis, kritis, dan reflektif. Masyarakat abad 21 ini dituntut untuk dapat mengadaptasi kemajuan teknologi dan keterbaruan/kekinian. Seperti yang disampaikan Gunawan Mohamad seorang budayawan (dalam Dinas Pendidikan, 2017), bahwa buku mengisi jam-jam kita yang kosong dengan percakapan yang mungkin tak akan pernah selesai, tapi membuat kita tahu: kita hanyalah penafsir tanda-tanda, di mana kebenaran menerangkan jejaknya. Itu sebabnya kata pertama yang menakjubkan adalah: "BACALAH". Kata Beliau sebuah quote yang sangat menarik tersebut menyampaikan pentingnya membaca untuk melihat kebenaran.

Bahwa perintah untuk membaca juga dengan jelas termaktub dalam kitab umat muslim, Alquran. Ketika sebuah pesan tersurat dengan jelas dalam Alquran maka apalagi yang harus dipertanyakan? Sebagai insan yang berilmu kita yang dikaruniai akal tentu saja harus menangkap makna dan ajaran Alquran tersebut dan menerapkannya dalam kehidupan. Membaca bisa menambah pengetahuan tentang kebenaran dan segala hal yang dibutuhkan manusia untuk mempelajari segala sesuatu yang dibutuhkan dalam menjalani hidup. Membaca berarti mampu meneruskan peradapan dari generasi ke generasi.

Deklarasi Praha (Unesco, 2003 dalam Kemdikbud, 2016: 1) ) mencanangkan pentingnya literasi informasi (information literacy), yaitu kemampuan untuk mencari, memahami, mengevaluasi secara kritis, dan mengelola informasi menjadi pengetahuan yang bermanfaat untuk pengembangan kehidupan pribadi dan sosialnya. Anis Baswedan (dalam Supiandi, 2016: 5) mengatakan bahwa salah satu ketrampilan yang harus dimiliki Sumber Daya Manusia (SDM) Indonesia di abad ke-21 adalah kemampuan literasi membaca. Kemampuan literasi atau keberaksaraan merupakan kemampuan seseorang yang tidak hanya diartikan sebagai kemampuan membaca dan menulis namun mencakup kemampuan dalam mengintepretasi sumber informasi dalam bentuk cetak, visual, digital, dan auditori. Bahkan sangatlah jelas menurut Ferguson (dalam Kemdikbud, 2016: 9) bahwa keamampuan literasi seseorang mencakup literasi dasar, literasi perpustakaan, literasi media, literasi teknologi, dan literasi fisual. Kemampuan tersebut kemudian berkembang menjadi literasi informasi yang memberikan pemahaman bagi seseorang mengenai informasi yang sedang dibaca atau ditulis secara kritis, analitis, dan reflektif.

Akan tetapi, pembelajaran di sekolah hingga saat ini belum mampu mewujudkan hal tersebut. Seperti yang disampaikan Kemdikbud (2015: 1) bahwa tantangan yang saat ini dihadapi adalah rendahnya minat baca. Selain ketersediaan buku di seluruh Indonesia belum memadai, pemerintah juga menghadapi 
rendahnya motivasi membaca di kalangan siswa. Hal ini memprihatinkan karena di era teknologi informasi, siswa dituntut untuk memiliki kemampuan membaca dalam pengertian memahami teks secara analitis, kritis, dan reflektif.

Hasil temuan Supiandi (2016: 3-4), bahwa sekolah sebagai tempat menimba ilmu belum sepenuhnya menumbuhkan budaya membaca dan menulis (literasi) sebagai bagian dari pengembangan diri siswa. Hal tersebut terlihat ketika bel istirahat sekolah berbunyi, siswa sebagian besar akan memilih kantin sekolah sebagai tempat untuk menghabiskan waktu istirahat dari pada perpustakaan. Pilihan siswa dalam menghabiskan waktu istirahat di kantin dari pada perpustakaan menunjukan bahwa kegiatan membaca belum menjadi suatu hal yang menarik bagi siswa.

Menurut Kemdikbud (2016), dalam konteks internasional, pemahaman membaca siswa Indonesia (selain matematika dan sains) pada tingkat sekolah menengah (usia 15 tahun) yang diuji oleh Organisasi untuk Kerja Sama dan Pembangunan Ekonomi (OECD_Organization for Economic Cooperation and Development) dalam Programme for International Student Assessment (PISA). PISA 2009 menunjukkan siswa Indonesia berada pada peringkat ke-57 dengan skor 396 (skor rata-rata OECD 493), sedangkan PISA 2012 menunjukkan siswa Indonesia berada pada peringkat ke-64 dengan skor 396 (skor rata-rata OECD 496) (OECD, 2013). Sebanyak 65 negara berpartisipasi dalam PISA 2009 dan 2012.

Berdasarkan persoalan tersebut di atas, menunjukkan bahwa praktik pendidikan yang dilaksanakan di sekolah tampaknya belum memperlihatkan fungsi sekolah sebagai organisasi pembelajar yang berupaya menjadikan semua warganya menjdi terampil membaca untuk mendukung mereka sebagai pembelajar sepanjang hayat. Literasi tidak boleh terpisahkan dari dunia pendidikan. Pembelajaran di sekolah semestinya menyiapkan Sumber Daya Manusia yang memiliki literasi. Literasi menjadi sarana siswa dalam mengenal, memahami, dan menerapkan ilmu yang didapatkannya di bangku sekolah. Literasi juga terkait dengan kehidupan peserta didik, baik di rumah maupun di lingkungan sekitarnya. Karena itu, pembelajaran di sekolah salah satunya yang mesti diperhatikan adalah proses menanamkan budaya membaca dan menulis (literasi) pada siswa.

Jamaruddin (2015) mengatakan bahwa seharusnya sekolah menjadi tempat awal melakukan gerakan literasi. Sekolah-sekolah ke depan harus berbasis literasi, artinya membaca dan menghasilkan karya menjadi dasar semua gerakan dan kegiatan sekolah. Agar siswa rajin membaca, guru harus bisa menjadi contoh. Oleh karena itu, tidak hanya 15 menit itu saja guru harus ikut membaca bersama siswa. Diselasela pembelajaran atau di saat-saat istirahat, mereka mestinya memperlihatkan pada siswa bahwa mereka rajin membaca, sehingga siswa terpengaruh mencontoh. Lebih lanjut Beliau mengatakan bahwa

Menurut Boyer (1997 dalam Nurohman, 2014: 12), memberdayakan peran 
literasi informasi merupakan tujuan penting dari pendidikan. Ia menyatakan bahwa informasi merupakan sumber yang sangat berharga. Pendidikan harus dapat memberdayakan semua orang untuk mendapatkan literasi informasi yang sesuai dengan kebutuhan.

Masih terdapat kesenjangan yang cukup tinggi antara tuntutan ideal pembelajaran di sekolah dalam fungsinya sebagai wahana pendidikan literasi dengan kondisi pembelajaran di sekolah yang ada sekarang. Dengan demikian, kebutuhan gerakan literasi sekolah semakin terasa dan mendesak. Gerakan Literasi Sekolah memperkuat gerakan penumbuhan budi pekerti sebagaimana dituangkandalam Peraturan Menteri Pendidikan dan Kebudayaan Nomor 23 Tahun 2015. Salah satu kegiatan di dalam gerakan tersebut adalah "kegiatan 15 menit membaca buku nonpelajaran sebelum waktu belajar dimulai". Kegiatan ini dilaksanakan untuk menumbuhkan minat baca siswa serta meningkatkan keterampilan membaca agar pengetahuan dapat dikuasai secara lebih baik. Materi baca berisi nilai-nilai budi pekerti, berupa kearifan lokal, nasional, dan global yang disampaikan sesuai tahap perkembangan siswa. Gerakan ini dilakukan melalui tiga tahapan: pembiasaan, pengembangan, dan pembelajaran.

Gerakan Literasi Sekolah sesungguhnya selaras dengan sembilan agenda prioritas (Nawacita), khususnya Nawacita nomor 5, 6, 8, dan 9. Butir Nawacita yang dimaksudkan adalah (5) meningkatkan kualitas hidup manusia dan masyarakat Indonesia; (6) meningkatkan produktivitas rakyat dan daya saing di pasar internasional sehingga bangsa Indonesia bisa maju dan bangkit bersama bangsabangsa Asia lainnya; (8) melakukan revolusi karakter bangsa; (9) memperteguh kebinekaan dan memperkuat restorasi sosial Indonesia. Empat butir Nawacita tersebut terkait erat dengan komponen literasi sebagai modal pembentukan sumber daya manusia yang berkualitas, produktif dan berdaya saing, berkarakter, serta nasionalis. Untuk dapat mengembangkan Nawacita,diperlukan pengembangan strategi pelaksanaan literasi di sekolah yang berdampak menyeluruh dan sistemik. Dalam hal ini, sekolah: a) sebaiknya tumbuh sebagai sebuah organisasi yang mengembangkan warganya sebagai individu pembelajar; b) perlu memiliki struktur kepemimpinan yang juga terkait dengan lembaga lain di atasnya, serta sumber daya yang meliputi sumber daya manusia, keuangan, serta sarana dan prasarana; dan c) memberikan layanan pendidikan dalam bentuk pembelajaran di dalam kelas dan berbagai kegiatan lain di luar kelas yang menunjang pembelajaran dan tujuan pendidikan.

Beragam program kegiatan gerakan literasi sekolah, salah satunya yang dapat dipilih melalui tantangan membaca yang diberi namaWest Java Leader's Reading Challange (WJLRC). WJLRC diartikan sebagai tantangan membaca yang ditunjukkan bagi para guru dan siswa di sekolah dari para pemimpin Jawa Barat (Disdik Prop. Jabar, 2016: 13). WJLRC diharapkan dapat memberi efek percepatan (akselerasi) terhadap GLS di Jawa barat. Hal ini dimungkinkan karena karakteristik 
kegiatan WJLRC yang cenderung masuk ke tahapan pengembangan (tahap kedua) dalam pentahapan pelaksanaan Gerakan Literasi Sekolah yang diprogramkan oleh Kementerian Pendididkan dan Kebudayaan' Kegiatan WJLRC dilaksanakan secara mandiri di sejumlah sekolah, dan merupakan implementasi hasil pelatihan guruguru Jawa Barat yang dikirim ke Australia Selatan sejak tahun 2012. Di Australia, kegiatan tantangan membaca untuk siswa dan guru ini telah dilaksanakan selama 14 tahun dalam program Premier'sReading Challenge. Secara formal, eksistensi kegiatan WJLRC telah dituangkan dalam Memorandum of Understanding, Sister Cooperation between West Java and South Australia Goverenment yang ditandatangani pada tahun 2015 oleh Gubernur Jawa Barat dan Premier (Kepala Pemerintahan Australia Selatan).

Tujuan dari study ini adalah untuk mendeskripsikan implemplementasi gerakan literasi berbasis West Java Leader's Reading Challange di SMP Negeri 3 Majalengka.

\section{METODE PENELITIAN}

Penelitian ini dilakukan di Sekolah Menengah Pertama Negeri (SMPN) 3 Majalengka Propinsi Jawa Barat tahun pelajaran 2016/ 2017. Metode yang digunakan dalam penelitian ini adalah metode kualitatif-deskriftif. Metode penelitian kualitatif adalah metode penelitian yang digunakan untuk meneliti pada kondisi objek alamiah (sebagai lawannya adalah eksperimen) dimana peneliti adalah sebagai instrumen kunci, teknik pengumpulan data dilakukan secara triangulasi data (gabungan), analisis data bersifat induktif, dan hasil penelitian kualitatif lebih menekankan makna dari pada generalisasi (Sugiyono: 2003: 8). Pada penelitian kualitatif data yang dikumpulkan umumnya berbentuk naratif, deskriptif, dalam kata-kata yang di teliti, dokumen pribadi, catatan lapangan, artifak, dokumen resmi dan video-tapes, transkrip (Moleong, 2007: 35). Sumber data diperoleh melalui kepala sekolah, guru, siswa, dan orang tua. Prosedur pengumpulan data dalam penelitian kualitatif melibatkan empat jenis dasar: pengamatan, wawancara, dokumen, dan gambar visual (Creswell: 2002: 143). Dalam pengumpulan data peneliti sebagai instrumen utama dengan dibantu oleh guru untuk menjaga keabsahan data. Penelitian ini menggunakan teknik trianggulasi. Tujuan trianggulasi digunakan oleh para peneliti kualitatif adalah untuk melakukan cross check data yang diperoleh dari lapangan. Teknik analisis data yang dilakukan yaitu analisis kualitatif. Fenomena yang nampak ditanyakan dan dikembangkan melalui wawancara mendalam kepada informan. Pada penelitian ini analisis data adalah upaya yang dilakukan dengan jalan bekerja dengan data, mengorganisasikan data, memilah-milahnya menjadi satuan yang dapat dikelola, mensintesiskannya, mencari dan menemukan pola, menemukan apa yang penting dan apa yang dipelajari, dan memutuskan apa yang dapat diceritakan kepada orang lain (Bogdan \& Biklen, 1982; dalam Moleong 2007). Analisis data dilakukan dalam 
tiga kegiatan yang saling terkait yaitu: mereduksi data, menampilkan data, verifikasi untuk menarik kesimpulan. Proses penelitian disajikan menurut tahaptahapnya, yaitu: Tahap Pra-lapangan,Tahap Kegiatan Lapangan, dan Tahap Pasca Lapangan.

\section{HASIL PENELITIAN DAN PEMBAHASAN \\ Konsep Gerakan Literasi Sekolah Melalui West Java Leader' s Reading Challange (WJLRC)}

Dalam rangka mewujudkan Gerakan Literasi Sekolah berbasis West Java Leader's Reading Challange (WJLRC) di SMP Negeri 3 Majalengka, penulis mendeskripsikan temuan hasil penelitian sebagai berikut.

\section{Konsep Gerakan Literasi Sekolah (GLS)}

Gerakan Literasi Sekolah (GLS) merupakan merupakan suatu usaha atau kegiatan yang bersifat partisipatif dengan melibatkan warga sekolah (siswa, guru, kepala sekolah, tenaga kependidikan, pengawas sekolah, Komite Sekolah, orang tua/wali murid peserta didik), akademisi, penerbit, media massa, masyarakat (tokoh masyarakatyang dapat merepresentasikan keteladanan, dunia usaha, dan lainlain.), dan pemangku kepentingan di bawah koordinasi Direktorat Jenderal Pendidikan Dasar dan Menengah Kementerian Pendidikan dan Kebudayaan.

GLS adalah gerakan sosial dengan dukungan kolaboratif berbagai elemen. Upaya yang ditempuh untuk mewujudkannya berupa pembiasaan membaca peserta didik. Pembiasaan ini dilakukan dengan kegiatan 15 menit membaca (gurumembacakan buku dan warga sekolah membaca dalam hati, yang disesuaikan dengan konteks atau target sekolah). Ketika pembiasaan membaca terbentuk, selanjutnya akan diarahkan ke tahap pengembangan, dan pembelajaran (diserta itagihan berdasarkan Kurikulum 2013). Variasi kegiatan dapat berupa perpaduan.

Secara umum tujuan gerakan literasi sekolah adalah untuk menumbuhkembangkan budi pekerti peserta didik melalui pembudayaan ekosistem literasi sekolah yang diwujudkan dalam Gerakan Literasi Sekolah agar mereka menjadi pembelajar sepanjang hayat. Sedangkan tujuan khusus dari Gerakan Literasi Sekolah adalah untuk :a) menumbuhkembangkan budaya literasi di sekolah; b) Meningkatkan kapasitas warga dan lingkungan sekolah agar literat; c) Menjadikan sekolah sebagai taman belajar yang menyenangkan dan ramah anak agar warga sekolah mampu mengelola pengetahuan; d) menjaga keberlanjutan pembelajaran dengan menghadirkan beragam buku bacaan dan mewadahi berbagai strategi membaca.

Dalam hal kompetensi literasi, literasi lebih dari sekadar membaca dan menulis, namun mencakup keterampilan berpikir menggunakan sumber-sumber pengetahuan dalam bentukcetak, visual, digital, dan auditori. Kemampuan ini disebut sebagai literasi informasi. Komponen literasi informasi terdiri atas literasi dini, literasi dasar, literasi perpustakaan, literasi media, literasi teknologi, dan literasi visual. Dalam konteks Indonesia, literasi dini diperlukan sebagai dasar pemerole- 
han berliterasi tahap selanjutnya. Komponen literasi tersebut dijelaskan sebagai berikut: Pertama, Literasi Dini (Early Literacy), yaitu kemampuan untuk menyimak, memahami bahasa lisan, dan berkomunikasi melalui gambar dan lisan yang dibentuk oleh pengalamannya berinteraksi dengan lingkungan sosialnya di rumah. Pengalaman peserta didik dalam berkomunikasi dengan bahasa ibu menjadi fondasi perkembangan literasi dasar.

Kedua, Literasi Dasar (Basic Literacy), yaitu kemampuan untuk mendengarkan, berbicara, membaca, menulis, dan menghitung (counting) berkaitan dengan kemampuan analisis untuk memperhitungkan (calculating), mempersepsikan informasi (perceiving), mengomunikasikan, serta menggambarkan informasi (drawing) berdasarkan pemahaman dan pengambilan kesimpulan pribadi. Ketiga, Literasi Perpustakaan (Library Literacy), antara lain, memberikan pemahaman cara membedakan bacaan fiksi dan nonfiksi, memanfaatkan koleksi referensi dan periodikal, memahami Dewey Decimal System sebagai klasifikasi pengetahuan yang memudahkan dalam menggunakan perpustakaan, memahami penggunaan katalog dan pengindeksan, hingga memiliki pengetahuan dalam memahami informasi ketika sedang menyelesaikan sebuah tulisan, penelitian, pekerjaan, atau mengatasi masalah.

Keempat, Literasi Media (Media Literacy), yaitu kemampuan untuk mengetahui berbagai bentuk media yang berbeda, seperti media cetak, media elektronik (media radio, media televisi), media digital (media internet), dan memahami tujuan penggunaannya. Kelima, Literasi Teknologi (Technology Literacy), yaitu kemampuan memahami kelengkapan yang mengikuti teknologi seperti peranti keras (hardware), peranti lunak (software), serta etika dan etiket dalam memanfaatkan teknologi. Berikutnya, kemampuan dalam memahami teknologi untuk mencetak, mempresentasikan, dan mengakses internet. Dalam praktiknya, juga pemahaman menggunakan komputer (Computer Literacy) yang didalamnya mencakup menghidupkan dan mematikan komputer, menyimpan dan mengelola data, serta mengoperasikan program perangkat lunak. Sejalan dengan membanjirnya informasi karena perkembangan teknologi saat ini, diperlukan pemahaman yang baik dalam mengelola informasi yang dibutuhkan masyarakat.

Keenam, literasi Visual (Visual Literacy), adalah pemahaman tingkat lanjut antara literasi media dan literasi teknologi, yang mengembangkan kemampuan dan kebutuhan belajar dengan memanfaatkan materi visual dan audiovisual secara kritis dan bermartabat. Tafsir terhadap materi visual yang tidak terbendung, baik dalam bentuk cetak, auditori, maupun digital (perpaduan ketiganya disebut teks multimodal), perlu dikelola dengan baik. Bagaimanapun di dalamnya banyak manipulasi dan hiburan yang benarbenar perlu disaring berdasarkan etika dan kepatutan.

Ihwal Literasi di Sekolah, mengacu pada metode pembelajaran Kurikulum 2013 yang menempatkan peserta didik sebagai subjek pembelajaran dan guru 
sebagai fasilitator, kegiatan literasi tidak lagi berfokus pada peserta didik semata. Guru, selain sebagai fasilitator, juga menjadi subjek pembelajaran. Akses yang luas pada sumber informasi, baik di dunia nyata maupun dunia maya dapat menjadikan peserta didik lebih tahu daripada guru. Oleh sebab itu, kegiatan peserta dalam berliterasi semestinya tidak lepas dari kontribusi guru, dan guru sebaiknya berupaya menjadi fasilitator yang berkualitas. Guru dan pemangku kebijakan sekolah merupakan figur teladan literasi di sekolah.

Dalam konteks sekolah, subjek dalam kegiatan literasi adalah peserta didik, pendidik, tenaga kependidikan (pustakawan, pengawas), dan kepala sekolah. Semua komponen warga sekolah ini berkolaborasi dalam Tim Literasi Sekolah (TLS) di bawah koordinasi kepala sekolah dan dikuatkan dengan SK kepala sekolah. TLS bertugas untuk membuat perencanaan, pelaksanaan, dan asesmen program. TLS dapat memastikan terciptanya suasana akademik yang kondusif, yang mampu membuat seluruh anggota komunitas sekolah antusias untuk belajar.

Praktik-praktik yang baik dalam gerakan literasi sekolah menekankan prinsip-prinsip sebagai berikut: a) Perkembangan literasi berjalan sesuai tahap perkembangan yang dapat diprediksi. Tahap perkembangan anak dalam belajar membaca dan menulis saling beririsan antartahap perkembangan. Memahami tahap perkembangan literasi peserta didik dapat membantu sekolah untuk memilih strategi pembiasaan dan pembelajaran literasi yang tepat sesuai kebutuhan perkembangan mereka; b) Program literasi yang baik bersifat berimbang. Sekolah yang menerapkan program literasi berimbang menyadari bahwa tiap peserta didik memiliki kebutuhan yang berbeda. Oleh karena itu, strategi membaca dan jenis teks yang dibaca perlu divariasikan dan disesuaikan dengan jenjang pendidikan. Program literasi yang bermakna dilakukan dengan memanfaatkan bahan bacaan kaya ragam teks, seperti karya sastra untuk anak dan remaja; c.Program literasi terintegrasi dengan kurikulum Pembiasaan dan pembelajaran literasi di sekolah adalah tanggung jawab semua guru di semua mata pelajaran sebab pembelajaran mata pelajaran apapun membutuhkan bahasa, terutama membaca dan menulis. Dengan demikian, pengembangan profesional guru dalam hal literasi perlu diberikan kepada guru semua mata pelajaran; d) Kegiatan membaca dan menulis dilakukan kapanpun, Misalnya, 'menulis surat kepada presiden' atau 'membaca untuk ibu' merupakan contoh-contoh kegiatan literasi yang bermakna; e) Kegiatan literasi mengembangkan budaya lisan Kelas berbasis literasi yang kuat diharapkan memunculkan berbagai kegiatan lisan berupa diskusi tentang buku selama pembelajaran di kelas. Kegiatan diskusi ini juga perlu membuka kemungkinan untuk perbedaan pendapat agar kemampuan berpikir kritis dapat diasah. Peserta didik perlu belajar untuk menyampaikan perasaan dan pendapatnya, saling mendengarkan, dan menghormati perbedaan pandangan; f) Kegiatan literasi perlu mengembangkan kesadaran terhadap keberagaman Warga sekolah perlu menghargai perbedaan melalui kegiatan literasi di sekolah. Bahan bacaan untuk 
peserta didik perlu merefleksikan kekayaan Indonesia agar mereka dapat terpajan pada pengalaman multikultural.

Bagaimana strategi membangun budaya literasi sekolah? Beberapa strategi untuk menciptakan budaya literasi yang positif di sekolah. Pertama, mengkondisikan lingkungan fisik ramah literasi Lingkungan fisik adalah hal pertama yang dilihat dan dirasakan warga sekolah. Oleh karena itu, lingkungan fisik perlu terlihat ramah dan kondusif untuk pembelajaran. Sekolah yang mendukung pengembangan budaya literasi sebaiknya memajang karya peserta didik dipajang di seluruh area sekolah, termasuk koridor, kantor kepala sekolah dan guru. Selain itu, karyakarya peserta didik diganti secara rutin untuk memberikan kesempatan kepada semua peserta didik. Selain itu, peserta didik dapat mengakses buku dan bahan bacaan lain di Sudut Baca di semua kelas, kantor, dan area lain di sekolah. Ruang pimpinan dengan pajangan karya peserta didik akan memberikan kesan positif tentang komitmen sekolah terhadap pengembangan budaya literasi.

Kedua, mengupayakan lingkungan sosial dan afektif sebagai model komunikasi dan interaksi yang literat Lingkungan sosial dan afektif dibangun melalui model komunikasi dan interaksi seluruh komponen sekolah. Hal itu dapat dikembangkan dengan pengakuan atas capaian peserta didik sepanjang tahun. Pemberian penghargaan dapat dilakukan saat upacara bendera setiap minggu untuk menghargai kemajuan peserta didik di semua aspek. Prestasi yang dihargai bukan hanya akademik, tetapi juga sikap dan upaya peserta didik. Dengan demikian, setiap peserta didik mempunyai kesempatan untuk memperoleh penghargaan sekolah. Selain itu, literasi diharapkan dapat mewarnai semua perayaan penting di sepanjang tahun pelajaran. Ini bisa direalisasikan dalam bentuk festival buku, lomba poster, mendongeng, karnaval tokoh buku cerita, dan sebagainya. Pimpinan sekolah selayaknya berperan aktif dalam menggerakkan literasi, antara lain dengan membangun budaya antar guru dan tenaga kependidikan. Dengan demikian, setiap orang dapat terlibat sesuai kepakaran masing-masing. Peran orang tua sebagai relawan gerakan literasi akan semakin memperkuat komitmen sekolah dalam pengembangan budaya literasi.

Ketiga, mengupayakan sekolah sebagai lingkungan akademik yang literat Lingkungan fisik, sosial, dan afektif berkaitan erat dengan lingkungan akademik. Ini dapat dilihat dari perencanaan dan pelaksanaan gerakan literasi di sekolah. Sekolah sebaiknya memberikan alokasi waktu yang cukup banyak untuk pembelajaran literasi. Salah satunya dengan menjalankan kegiatan membaca dalam hati dan guru membacakan buku dengan nyaring selama 15 menit sebelum pelajaran berlangsung. Untuk menunjang kemampuan guru dan staf, mereka perlu diberikan kesempatan untuk mengikuti program pelatihan tenaga kependidikan untuk peningkatan pemahaman tentang program literasi, pelaksanaan, dan keterlaksanaannya.

Berikut ini adalah tabel Ekosistem Sekolah yang Literat: 
a. Lingkungan Fisik

1) Karya peserta didik dipajang di sepanjang lingkungan sekolah, termasuk koridor dan kantor (kepala sekolah, guru, administrasi, bimbingan konseling).

2) Karya peserta didik dirotasi secara berkala untuk memberi kesempatan yang

seimbang kepada semua peserta didik.

3) Buku dan materi bacaan lain tersedia di pojok-pojok baca di semua ruang kelas.

4) Buku dan materi bacaan lain tersedia juga untuk peserta didik dan orang tua/

pengunjung di kantor dan ruangan selain ruang kelas.

5) Kantor kepala sekolah memajang karya peserta didik dan buku bacaan untuk

Anak.

6) Kepala sekolah bersedia berdialog dengan warga sekolah.

b. Lingkungan Sosial dan Afektif

1) Penghargaan terhadap prestasi peserta didik (akademik dan nonakademik) diberikan secara rutin (tiap minggu/bulan). Upacara hari Senin merupakan salah

satu kesempatan yang tepat untuk pemberian penghargaan mingguan.

2) Kepala sekolah terlibat aktif dalam pengembangan literasi

3) Merayakan hari-hari besar dan nasional dengan nuansa literasi, misalnya merayakan Hari Kartini dengan membaca surat-suratnya.

4) Terdapat budaya kolaborasi antarguru dan staf, dengan mengakui kepakaran

masing-masing.

5) Terdapat waktu yang memadai bagi staf untuk berkolaborasi dalam menjalankan

program literasi dan hal-hal yang terkait dengan pelaksanaannya

6) Staf sekolah dilibatkan dalam proses pengambilan keputusan, terutama dalam

menjalankan program literasi

c. Lingkungan Akademik

1) Terdapat TLS yang bertugas melakukan asesmen dan perencanaan. Bila diperlukan, ada pendampingan dari pihak eksternal 
2) Disediakan waktu khusus dan cukup banyak untuk pembelajaran dan pembiasaan

literasi: membaca dalam hati (sustained silent reading), membacakan buku dengan nyaring (reading aloud), membaca bersama (shared reading), membaca

terpandu (guided reading), diskusi buku, bedah buku, presentasi (showand-tell

presentation).

3) Waktu berkegiatan literasi dijaga agar tidak dikorbankan untuk kepentingan lain

4) Disepakati waktu berkala untuk TLS membahas pelaksanaan gerakan literasi

sekolah.

5) Buku fiksi dan nonfiksi tersedia dalam jumlah cukup banyak di sekolah. Buku

cerita fiksi sama pentingnya dengan buku berbasis ilmu pengetahuan

Gerakan literasi dilaksanakan dalam tiga tahapan, yaitu pembiasaan, pengembangan dan pembelajaran. Masing-masing tahapan dapat dideskripsikan sebagai berikut. Pertama, Tahap Pembiasaan. Tujuan untuk menumbuhkan rasa cinta membaca di kalangan siswa. Prinsip, yaitu tidak ada tagihan. Jenis tagihan, yaitu: 1) lima belas menit membaca sebelum jam pelajaran; 2) pembuatan jurnal membaca siswa; 3) penyiapan sarana literasi (penyediaan area baca, buku bacaan dan akses internet); 4) menciptakan lingkungan sosial dan afektif yang nyaman untuk membaca; 5) pembimbingan e-literasi secara bertanggung jawab; dan 6) memperkenalkan etika perilaku dan hukum dalam menggunakan teknologi informasi dan komunikasi. Indikator ketercapaian, yaitu: 1) ada program dan pelaksanaan 15 menit membaca; 2) tersedia jurnal membaca; 3) tersedia area baca di sekolah (perpustakaan, sudut buku kelas dan tempat-tempat lain untuk membaca; dan 4) pembimbingan penggunaan internet.

Kedua, Tahap Pengembangan. Tujuan untuk pengembangan minat baca untuk meningkatkan kemampuan literasi secara digital dan nondigital. Prinsip, yaitu ada tagihan non akademik. Jenis kegiatan, yaitu: 1) lima belas menit membaca sebelum jam pelajaran; 2) pembuatan respon bacaan: graphic organizers, peta cerita, penilaian non akademik; 3) pembuatan bahan kaya teks oleh siswa; 4) pembimbingan penggunaan komputer dan internet untuk kegiatan literasi; dan 5) pengenalan penggunaan berbagai bahan referensi cetak dan digital untuk mencari informasi. Indikator Ketercapaian, yaitu: 1) ada program dan pelaksanaan 15 menit membaca; 2) tersedia berbagai bentuk hasil tagihan non akademik; 3) tersedia 
bahan kaya teks yang dikoleksi dan dipajang; 4) dilaksanakannya pembimbingan penggunaan komputer dan internet; dan pembimbingan penggunaan bahanbahan literasi digital.

Ketiga, Tahap Pembelajaran. Tujuan untuk meningkatkan kemampuan literasi di semua mata pelajaran dengan menggunakan bahan-bahan pengayaan, baik secara digital maupun non digital. Prinsip, yaitu ada tagihan akademik di seluruh mata pelajaran. Jenis kegiatan, yaitu: 1) lima belas menit membaca sebelum jam pelajaran; 2) pemamfaatan berbagai strategi literasi dalam pembelajaran; 3) pengembangan kemampuan e-literasi dalam pembelajaran bagi guru dan siswa ; 4) penilaian akademik; 5) pengembangan lingkungan fisik, sosial, afektif, dan akademik; dan 6) memilih cara dan jenis e-literasi yang tepat untuk proses pembelajaran, produksi pengetahuan, dan menyebarkannya di kalangan warga sekolah. Indikator Ketercapaian, yaitu: 1) ada program dan pelaksanaan 15 menit membaca; 2) penyusunan dan pelaksanaan strategi literasi dalam pembelajaran; 3 ) tersedia area baca di sekolah (perpustakaan, sudut buku kelas, dan tempat-tempat lain untuk membaca; dan 4) pembimbingan penggunaan internet.

\section{Konsep West Java Leader' s Reading Challange (WJLRC)}

Dalam rangka menyukseskan Gerakan Literasi Sekolah yang digulirkan Kementerian Pendidikan dan Kebudayaan, Pemerintah Propinsi Jawa Barat secara bertahap memperluas pelaksanaan kegiatan West Java Leader's Reading Challenge (WJLRC), dimulai pada jenjang pendidikan dasar (SD) dan SMP) dan akan berlanjut pada jenjang pendidikan menengah.

Secara harfiah, WJLRC diartikan sebagai tantangan membaca yang ditunjukkan bagi para guru dan siswa di sekolah dari para pemimpin di Jawa Barat. Leader (pemimpin) yang dimaksud dalam kegiatan ini adalah para pemimpin pemerintah tertinggi dalam suatu wilayah; kepala sekolah, lurah, camat, bupati, walikota, gubernur hingga presiden. Dalam kegiatan WJLRC tahun 2016, yang menjadi penantangnya adalah Gubernur Jawa Barat dan Kepala Dinas Pendidikan Propinsi Jawa Barat yang bekerja sama dengan South Australia Departemen for Education and Children Development.

Wujud kegiatan WJLRC di sekolah adalah terbentuknya kelompok siswa yang melakukan aktivitas membaca, menulis, dan diskusi buku secara terprogram di luar jam pelajaran, di bawah bimbingan guru yang ditugaskan untuk menjadi pembimbing. Kelompok ini melakukan aktivitas dalam rangka menjawab tantangan, mampukah mereka secara tuntas membaca sejumlah buku yang dibaca minimal 24 buku dalam waktu sepuluh bulan.

Sebagai sebuah tantangan, maka sepantasnya kepada yang sukses menjawab tantangan itu, diberikan apresiasi atau penghargaan oleh pemimpin yang memberikan tantangan tersebut. Bentuk apresiasi dapat berupa piagam, medali 
atau bentuk lain yang sifatnya mengapresiasi dan menumbuhkan motivasi. jenis penghargaan yang akan didapatkan oleh peserta WJLRC yang lulus dalam tantangan menmbaca, yaitu: 1) peserta berhasil mengeksplorasi minimal 24 buku ( 2 buku bahasa Sunda) dalam 10 bulan, berhak atas medali dan sertifikat Pionir WJLRC 2016-2017; 2) Setiap guru pembimbing/perintis berhak atas sertifikat pelatihan dan penerapan pendidikan literasi, dari Dinas Pendidikan Provinsi Jawa Barat, jika berhasil membimbing 80\% WJLRC; 3) setiap sekolah yang sukses membantu peserta WJLRC dalam menuntaskan tantangan selama 10 bulan hingga 100\%, berhak mendapatkan piagam sebagai Sekolah Inspiratif.

WJLRC diharapkan dapat memberi efek percepatan (akselerasi) terhadap pelaksanaan GLS di Jawa Barat. Hal ini dimungkinkan karena karakteristik kegiatan WJLRC yang cenderung masuk ke tahapan pengembangan (tahap kedua) dalam pentahapan pelaksanaan Gerakan Literasi Sekolah yang diprogramkan oleh Kementerian Pendidikan dan Kebudayaan.

Pelaksanaan WJLRC dimaksudkan untuk mencapai tujuan berikut: 1) membangun budaya literasi (kegiatan keberaksaraan) di lingkungan sekolah dan masyarakat luas; 2) memotivasi siswa untuk bisa menemukan banyak hal yang menarik dan berguna dari beragam buku; 3) meningkatkan keterampilan berdiskusi secara positif di komunitas sekolah, ke.uarga, dan masyarakat; 4) meningkatkan keharmonisan komunikasi antara orang tua dengan guru dan keterlibatan nyata orang tua dalam proses belajar anak-anaknya.

Keunggulan program WJLRC adalah sebagai berikut: 1) pola pelaksanaan yang terstruktur (ada tahapan membaca, mereviu, presentasi, diskusi dan menyebarkan karya tulis) dalam perioder tertentu; 2) waktu pelaksaan yang berkesinambungan' 3) pemberian penghargaan kepada kepala sekolah, guru dan peserta didik yang dapat menyelesaikan tantangan. Penghargaan, yaitu: 1) Peserta yang berhasil mengeksplorasi minimal 24 buku, berhak atas medali dan sertifikat Pionir 20162017; 2) Setiap guru pembimbing/perintis berhak atas sertifikat Pelatihan dan Penerapan Pendidikan Literasi dari Dinas Pendidikan Propinsi Jawa Barat, jika berhasil membimbing minimal 80\% WJLRC; 3) Setip sekolah yang sukses membantu hingga 100\% peserta WJLRC menuntaskan tantangan selama sepuluh bulan berhak atas piagam penghargaan dari Gubernur Jawa Barat sebagai Sekolah Inspiratif.

Pelaksanaan WJLRC di sekolah hanya dapat terwujud melalui keterlibatan berbagai pihak seperti penggerak literasi, perintis literasi (kepala sekolah dan guru pembimbing), siswa, pustakawan, orang tua, dan masyarakat. Semua pihak memiliki tugas dan peran masing-masing, yaitu: Pertama, peran penggerak literasi adalah pengawas, Kepala Sekolah, atau guru yang secara khusus ditugaskan untuk melakukan pendampingan dan meberikan bantuan teknis untuk memastikan agar kegiatan GLS dan WJLRC di setiap sekolah pelaksanaannya dapat berjalan sebagaimana mestinya. Peran penggerak literasi di antaranya: 1) menjadi guru 
pembimbing minimal satu kelompok (5 siswa) WJLRC di sekolah tempat tugasnya; 2) mengkoordinasikan dan mendampingi pelaksanaan WJRLC sekolah-sekolah sesuai dengan penugasan. Penggerak juga perlu melibatkan diri dalam kegiatan diskusi buku sekurang-kurangnya satu kali dalam setahun di masing-masing sekolah selama masa penugasan; 3) melakukan monitoring dan evaluasi pelaksanaan Gerakan Literasi sekolah dan memeriksa rekap portofolio/laporan fisik hasil reviu siswa serta dokumentasi foto-foto kegiatan dari sekolah yang didampinginya; 4) menerima laporan online dari guru pembimbing dan menggugahnya ke web sesuai jadwal; 5) menjembatani komunikasi antara sekolah dengan tim Gerakan Literasi Sekolah Dinas Pendidikan Propinsi Jawa Barat.

Kedua, peran kepala sekolah. Kepala sekolah pelaksana WJLRC merupakan bagian dari komunitas perintis literasi sekolah. Sebagai pemimpin, kepala sekolah memiliki peran penting dan sangat menentukan dan sangat menentukan dalam pelaksanaan GLS dan WJLRC, antara laian: 1) menetapkan kebijakan sekolah untuk melaksanakan WJLRC sebagai salah satu program/kegiatan utama dan mendapat dukungan penuh di sekolah; 2) menetapkan guru yang secara khusus ditugaskan untuk menjadi pembimbing kegiatan WJLRC; 3) melakukan sosialisasi kepada guru, siswa orang rua dan seluruh warga sekolah, sekaligus mempromosikan kegiatan WJL RC agar mendapat respon optimal dari seluruh warga sekolah, 4) memonitor pelaksanaan dan perkembangan WJLRC di sekolah, memberi semangat dan dukungan, serta turut mengupayakan solusi, apabila terdapat kendala atau permasalahan dalam pelaksanaan WJLRC; 5) menetapkan agenda pelaksanaan Readathon, yaitu kegiatan membaca masal selama 42 menit yang didikuti oleh sebanyak mungkin warga sekolah, secara periodik; 6) memfasilitasi pemberian apresiasi dan promosi dalam berbagai bentuk kepada siswa yang konsisten dan sungguh-sungguh mengikuti kegiatan WJLRC.

Ketiga, Peran perintis literasi (Guru Pembimbing), yaitu: 1) Melakukan sosialisasi kepada siswa dan orang tua; 2) menerima pendaftaran calon peserta yang siap berkomitmen memenangkan tantangan selama 10 bulan; 3) membentuk kelompok diskusi WJLRC; 4) mendaftarkan data siswa peserta ke website WJLRC; 5) bekerja sama dengan orang tua dalam memvalidasi kepantasan buku yang akan dibaca; 6) memverifikasi kartu peserta WJLRC; 7) mendokumentasikan dan mengawasi jalannya diskusi kelompok; 8) memotivasi peserta untuk melengkapi portofolio reviu bukunya dan mengirimkannya website WJLRC secara rutin perbulan; 9) mengikuti kegiatan tantangan dengan membaca, mereviu dan mendiskusikan 10 buku dalam 10 bulan, satu diantaranya buku berbahasa daerah/Sunda (buku minimal 150 halaman); 10) mencatat jurnal kegiatan WJLRC di sekolahnya sebagai bentuk evaluasi program, menuliskan ide, inovasi), merekap kartu peserta online.

Keempat, Peran siswa. Siswa adalah peserta literasi yang yang mendaftar dalam kegiatan WJLRC". Perannya, yaitu: 1) mendaftarkan diri dengan menyertakan persetujuan tertulis dari orang tua; 2) aktif dan secara konsisten mengikuti 
kegiatan yang diprogramkan dalam kelompok membaca, yaitu: a) membaca minimal 24 buku dalam 10 bulan (termasuk buku berbahasa daerah);b) menulis reviu dari semua buku yang dibaca dan menyetorkan hasil reviu tersebut kepada guru; c) presentasi dan diskusi buku; 3) membuat buku harian untuk menuliskan pengalaman sehari-hari dalam rangka menumbuhkan kebiasaan menulis. Setiap tulisan minimal 50 kata dan memuat pengalaman berkesan tidak bersifat rahasia dan tidak mengandung SARA, serta memugkinkan dan bermanfaat jika dibaca oleh orang lain.

Kelima, Peran Pustakawan, yaitu: 1) menyiapkan buku-buku koleksi perpustakaan yang akan dibaca siswa;2)membantu guru pembimbing dalam memvalidasi buku yang akan dibaca; 3) menciptakan suasan kondusif untuk kegiatan WJLRC; 4) memberikan motivasi kepada peserta literasi; 5) bekerjasama dengan guru pembimbing dalam melakukan setiap tahapan WJLRC. Keenam, Peran Orang Tua, yaitu: 1) membantu siswa mendapatkan sumber yang bermutu;2) bekerja sama dengan guru pembimbing dalam memvalidasi buku yang akan dibaca;3) memeriksa kartu prestasi WJLRC; 4) memotivasi peserta untuk rajin membaca, melengkapi portofolio reviu dan melaporkan hasil reviu kepada guru pembimbing; 5) menemani siswa berlatih berdiskusi dan mempresentasikan reviu buku bacaannya.

\section{Implementasi Gerakan Literasi Sekolah Melalui West Java Leader' s Reading Challange (WJRLC) Di SMP Negeri 3 Majalengka}

Tantangan membaca dalam WJLRC di SMPN 3 Majalengka Kabupaten tahun pelajaran 2016/2017 dilaksanakan selama 10 bulan, mulai bulan September 2016 sampai dengan bulan Juni 2017, dan diikuti oleh siswa kelas 8 sebanyak 40 orang.

Langkah-langkah kegiatan WJLRC di SMPN 3 Majalengka adalah sebagai berikut: Pertama, sosialisasi program WJLRC kepada guru, siswa, orang tua dan seluruh warga sekolah. Berikut ini adalah uraian kegiatan sosialiasi program WJLRC di SMPN 3 Majalengka. Pada Sabtu (13/9) pukul 08.00WIB, seluruh warga sekolah SMPN 3 Majalengka menerima paparan sosialisasi kegiatan WJLRC secara massal di aula sekolah. Acara diawali dengan sambutan dari kepala sekolah SMPN 3 Majalengka. Dalam sambutannya pada kegiatan WJLRC di SMPN 3 Majalengka Obay Sobari, S.Pd mengajak para siswa siswi SMPN 3 Majalengka untuk gemar membaca karena manfaat membaca sangat besar dalam kehidupan sehari-hari. "Mari, anak-anak rajinlah membaca karena dengan membaca kita banyak mendapat informasi, ilmu ,dan dunia. Selain itu manfaatkan pula buku-buku yang ada di perpustakaan, karena buku adalah jendela dunia" tuturnya. Selain itu, Teteng, S.Pd, M.Pd sebagai ketua WJLRC sekolah tersebut. juga mengajak seluruh keluarga besar SMPN 3 Majalengka terutama orang tua siswa untuk mendampingi dan memotivasi putra-putrinya agar gemar membaca. Selain itu dalam sambutannya juga beliau mengajak siapa saja untuk menyumbangkan buku-buku yang masih 
layak baca ataupun buku-buku baru dalam rangka memperkaya sumber bacaan di SMPN 3 Majalengka. Mengakhiri sambutannya beliau mengatakan bahwa kegiatan Readhaton akan dilakukan setiap hari Jumat dari pukul 13.00- 13.42 WIB.

Setelah acara sambutan barulah acara sosialisasi materi tentang WJLRC yang di sampaikan oleh Bapak Tetetng, M. Pd selaku ketua dan guru perintis di SMPN 3 Majalengka. Pemaparan materi dimulai dari tujuan kegiatan WJLRC, pembagian tugas dan peran, pelaksanaan dan pengembangan WJLRC di sekolah, bentuk dan tahap kegiatan WJLRC di sekolah, penghargaan, dan indikator keberhasilan WJLRC.

Kegiatan ini disambut baik oleh semua pihak, lebih dari 1000 siswa, guru-guru, komite sekolah, dan puluhan orang tua siswa mengikuti sosialisasi WJLRC dengan antusias. Dalam kegiatan sosialisasi ini pula pihak sekolah langsung memotivasi seluruh warga sekolah untuk gemar membaca melalui kegiatan Readhaton. Kegiatan Readhaton adalah kegiatan membaca cepat secara kolosal selama 42 menit. Ketika Readhaton seluruh siswa, guru, orang tua, dan kepala sekolah yang hadir sudah membawa buku dari rumah. Seluruhnya serempak membaca bersama-sama di lapangan sekolah.

Kegiatan readhaton diakhiri dengan presentasi hasil review oleh beberapa siswa di antaranya oleh Reza Andriany perwakilan siswa Kelas V III A yang memaparkan hasil reviunya di depan seluruh siswa "Saya membaca buku cerita perwakilan guru, yaitu Bapak Nana Suhana, M.Pd, yang memaparkan hasil reviunya di depan seluruh siswa "Saya membaca buku cerita yang berjudul Inginku, Alasan saya memilih buku ini karena tertarik dan penasaran terhadap judulnya, Isi cerita pada buku ini menceritakan tentang " kangker serviks bisa datang kepada siapa saja. Mari kita cegah kanker serviks dan menyelamatkan perempuan Indonesia dari ancaman pembunuhan nomor satu ini.

Kedua, merekruit peserta WJLRC melalui hasil evaluasi pelaksanaan Gerakan Literasi Sekolah. Berikut ini adalah daftar nama WJLRC SMP Negeri 3 Majalengka.

\begin{tabular}{lllll}
\hline No & Nama & Kelas & Nama Kelompok & Nama Pembimbing \\
\hline 1. & Rezza Andriany & VIII I & ShalahudinAl Ayubi & Ani Nurhayati, S.Pd \\
2. & Hedita Sisdawika & VIII A & & \\
3. & Hidayatul Shaffira & VIII A & & \\
4. & Itsina Nur Maelani Usmani & VIII A & & \\
5. & Zahra Nia Salasabila & VIII A & & \\
6. & Adriety Bhanulaksmi Lintang P. & VIII B & Khalid Bin Walid & Frans Sugara, S.Pd \\
7’ & Cindy Fayza Rahma & VIII B & & \\
8, & Dinda Nur Maulidah & VIII B & & \\
9. & Fazia Zhafirah Lesmana & VIII B & & \\
10. & Siti Zulfa Nur Rahma & VIII I & & \\
\hline
\end{tabular}




\begin{tabular}{|c|c|c|c|c|}
\hline $\begin{array}{l}11 . \\
12 . \\
13 . \\
14 . \\
15 .\end{array}$ & $\begin{array}{l}\text { Bagaspati Wiradarma } \\
\text { Elma Rahmawati } \\
\text { Firman Fudyansyah } \\
\text { Manik Nurul Alfiyah } \\
\text { Nabila Rihadatul Aisy }\end{array}$ & $\begin{array}{l}\text { VIII C } \\
\text { VIII C } \\
\text { VIII C } \\
\text { VIII C } \\
\text { VIII C }\end{array}$ & $\begin{array}{l}\text { Khodijah Binti Khu- } \\
\text { walid }\end{array}$ & Iis Rismawati, M.Pd \\
\hline $\begin{array}{l}16 . \\
17 . \\
18 . \\
19 . \\
20 .\end{array}$ & $\begin{array}{l}\text { Bemby Putri Nursyfa } \\
\text { Imanuel Bagas Raja Siregar } \\
\text { Salfa Syahira } \\
\text { Widya Puspita Azzahra } \\
\text { Zahra Sofia Nur'azzizah }\end{array}$ & $\begin{array}{l}\text { VIII D } \\
\text { VIII D } \\
\text { VIII D } \\
\text { VIII D } \\
\text { VIII D }\end{array}$ & Husain Bin Ali & Jamilatun Falita, S.Pd \\
\hline $\begin{array}{l}21 . \\
22 . \\
23 . \\
24 . \\
25 .\end{array}$ & $\begin{array}{l}\text { Aulia Esa Febrianti } \\
\text { Herda Cahyaningrum } \\
\text { Tsari Alfyani Sufyan } \\
\text { Sadrina Altafh Nurhasna } \\
\text { Monica Anglia Sianto }\end{array}$ & $\begin{array}{l}\text { VIII E } \\
\text { VIII E } \\
\text { VIII E } \\
\text { VIII E } \\
\text { VIII E }\end{array}$ & Bilal Bin Rabbah & Eulis Delis, S.Pd \\
\hline $\begin{array}{l}26 . \\
27 . \\
28 . \\
29 . \\
30 .\end{array}$ & $\begin{array}{l}\text { Destarika Wirayuda Hidayat } \\
\text { Rosalynda Monica Lestari } \\
\text { Twenty Yanuar Nurazizah } \\
\text { Vany Hapipah Adawiah } \\
\text { Wilda Rifa Fadhilah }\end{array}$ & $\begin{array}{l}\text { VIII F } \\
\text { VIII F } \\
\text { VIII F } \\
\text { VIII F }\end{array}$ & Thariq Bin Ziad & Iin Kurniasih, S.Pd \\
\hline $\begin{array}{l}31 . \\
32 . \\
33 . \\
34 . \\
35 .\end{array}$ & $\begin{array}{l}\text { Audri Luticia Almira Sugandi } \\
\text { Muhamad Faisal Faturrahman } \\
\text { Silmi Aghniya Ahmad P. } \\
\text { Sri Pratiwi Lestari } \\
\text { Vidianova Radian Rahman }\end{array}$ & $\begin{array}{l}\text { VIII G } \\
\text { VIII G } \\
\text { VIII G } \\
\text { VIII G } \\
\text { VIII G }\end{array}$ & Zaid Bin Harisah & Ihat Solihat, S.Pd \\
\hline $\begin{array}{l}36 . \\
37 . \\
38 . \\
39 . \\
40 .\end{array}$ & $\begin{array}{l}\text { Melia Nuraeni } \\
\text { Rizki Amelia } \\
\text { Naila Fathiyah Mufarrihah S. } \\
\text { Prima Dhea Carrisa } \\
\text { Sifa Wihdatul Hasanah }\end{array}$ & $\begin{array}{l}\text { VIII H } \\
\text { VIII H } \\
\text { VIII H } \\
\text { VIII H } \\
\text { VIII H }\end{array}$ & Abdulah Bin Zubair & Teteng, M.Pd \\
\hline
\end{tabular}

Ketiga, menyelenggarakan kegiatan membaca buku, menulis reviu, diskusi buku, dan melaporkan pada Website WJLRC dengan bimbingan guru secara terprogram bagi siswa peserta kelompok membaca. Kegiatan membaca. Pada minggu pertama, peserta memilih buku-buku yang akan dibacanya. Buku-buku tersebut harus diperhatikan dan dikonsultasikan kepada guru pembimbing, pustakawan atau orang tua. Setelah mendapat persetujuan, maka siswa dapat memulai membaca buku tersebut. Kegiatan membaca dilakukan di rumah. Pada minggu kedua, siswa mereviu buku-buku yang telah dibacanya. Teknik penulisan reviu dapat dilakukan dengan berbagai cara, yaitu paparan tiga paragraf yang memuat alasan memilih buku tersebut, ringkasan isi buku, serta amanat/ pesan moral yang siswa dapatkan setelah membaca buku tersebut, teknik model modifikasi ishikawa fish bone ataupun Y Chart. Pada Minggu ketiga pembimbing mengumpulkan peserta WJRLC untuk melaksanakan diskusi, siswa dipersilahkan secara bergiliran untuk menyampaikan isi buku yang telah dibacanya dalam waktu empat menit tanpa jeda, setelah itu dilaksanakan tanya jawab. Hal-hal yang dapat 
ditanyakan guru atau orang tua saat kegiatan diskusi, di antaranya: 1) Apa tema dari buku yang sedang atau sudah dibaca? 2) Mengapa siswa tertarik membaca buku tersebut? 3) Apa yang siswa ketahui tentang penulis buku itu? 4) Apakah hal/ bagian menarik dari buku yaang sudah dibaca? 5) Adakah hal yang tidak disuakai dalam bukunya? Mengapa? 6) Jika siswa memilih buku cerita atau novel, mintalah ia; a) menyebutkan dan menggambarkan tokoh-tokoh dalam buku ceritanya; b) menyebutkan dan menggambarkan tempat yang menjadi latar belakang cerita; c) menjelaskan waktu atau masa saat cerita itu terjadi; d) saat ia bisa memilih peran, ia akan menjadi tokoh yang mana? Dengan alasan? 7) Maukah ia membaca buku yang sama di lain waktu? 8) Apakah ia akan merekomendasikan/mengajak orang lain membaca buku itu? 9) Apakah ia mendapatkan inspirasi positif setelah membacanya? Dan 10) pertanyaan-pertanyaan lain dan tema perbincangan dapat dikembangkan sesuai situasi dan kondisi.

Melaporkan pada Website WJLRC. Pada minggu keempat, guru pembimbing melaporkan hasil reviu siswanya disertai dengan foto-foto kegiatan. Kumpulan reviu dari kelima peserta berserta fotonya dibuat satu file dan bisa dikirim ke Website WJLRC sesuai jadwal. Untuk dokumentasi di sekolah hard copy reviu dapat dikumpulkan pada folder masing-masing siswa yang sudah diberi identitas.

Keberhasilan Gerakan Literasi Sekolah berbasis WJLRC di SMP Negeri 3 Majalengka tampak dari hal-hal berikut. Pertama, Gerakan membaca menjadi aktivitas keseharian seluruh warga sekolah. Hal ini terlihat dari: 1) sekolah secara rutin melaksanakan kegiatan membaca 15 menit sebelum jam pelajaran dimulai;2) tersedia dan dimanfaatkannya sarana dan prasarana membaca seperti perpustakaan , pojok baca dan lain-lain; 3) meningkatnya jumlah kunjungan siswa dan guru ke perpustakaan sekolah; 4) Terlaksananya Readhaton atau kegiatan membaca massal lainnya secara periodik. Kedua, Terbentuknya komunitas siswa membaca melalui kegiatan West Java Leader's Reading Challenge (WJLRC). Hal ini tampak dari: 1) meningkatnya jumlah buku yang dibaca dan dibuat reviunya oleh siswa; 2) meningkatnya kecepatan membaca siswa peserta kegiatan WJLRC; 3) adanya kesinambungan dan keberlanjutan kegiatan WJLRC antar kelas. Ketiga, Publikasi tulisan karya literasi siswa dan guru. Hal ini tampak dari adanya bukti aktivitas dan karya literasi siswa serta guru pada website WJLRC. Keempat, meningkatnya dukungan orang tua dan masyarakat terhadap gerakan literasi sekolah. Hal ini tampak dari: 1) adanya keterlibatan langsung orang tua dan masyarakat dalam berbagai kegiatan gerakan literasi sekolah; 2) meningkatnya dukungan dan kepedulian orang tua dan masyarakat terhadap upaya penumbuhan budaya baca di rumah dan lingkungan masyarakat; 3) adanya donasi buku untuk sekolah dari orang tua dan masyarakat. 


\section{KESIMPULAN}

Gerakan Literasi Sekolah adalah gerakan sosial dengan dukungan kolaboratif berbagai elemen seperti siswa, guru, kepala sekolah, tenaga kependidikan, pengawas sekolah, komite sekolah, orang tua/wali murid). Upaya yang ditempuh untuk mewujudkannya berupa pembiasaan membaca siswa. Pembiasaan ini dilakukan dengan kegiatan 15 menit membaca (guru membacakan buku dan warga sekolah membaca dalam hati, yang disesuaikan dengan konteks atau target sekolah). Ketika pembiasaan membaca terbentuk, selanjutnya akan diarahkan ke tahap pengembangan, dan pembelajaran disertai tagihan berdasarkan Kurikulum. WJLRC dalam kontek gerakan literasi sekolah sebagai tahap pengembangan.

WJLRC diartikan sebagai tantangan membaca yang ditunjukkan bagi para guru dan siswa di sekolah dari para pemimpin di Jawa Barat. Leader (pemimpin) yang dimaksud dalam kegiatan ini adalah para pemimpin pemerintah tertinggi dalam suatu wilayah; kepala sekolah, lurah, camat, bupati, walikota, gubernur hingga presiden. Dalam kegiatan WJLRC tahun 2 016, yang menjadi penantangnya adalah Gubernur Jawa Barat dan Kepala Dinas Pendidikan Propinsi Jawa Barat yang bekerja sama dengan South Australia Departemen for Education and Children Development.

Wujud kegiatan WJLRC di sekolah adalah terbentuknya kelompok siswa yang melakukan aktivitas membaca, menulis, dan diskusi buku secara terprogram di luar jam pelajaran, di bawah bimbingan guru yang ditugaskan untuk menjadi pembimbing. Kelompok ini melakukan aktivitas dalam rangka menjawab tantangan, mampukah mereka secara tuntas membaca sejumlah buku yang dibaca minimal 24 buku dalam waktu sepuluh bulan.

Keberhasilan implementasi Gerakan Literasi Sekolah berbasis West Java Leader's Reading Challenge (WJLRC) di SMP Negeri 3 Majalengka ditunjukkan dari hal-hal berikut. Pertama, gerakan membaca menjadi aktivitas keseharian seluruh warga sekolah. Hal ini terlihat dari: 1) sekolah secara rutin melaksanakan kegiatan membaca 15 menit sebelum jam pelajaran dimulai;2) tersedia dan dimanfaatkannya sarana dan prasarana membaca seperti perpustakaan, pojok baca dan lain-lain; 3) meningkatnya jumlah kunjungan siswa dan guru ke perpustakaan sekolah; 4) terlaksananya Readhaton atau kegiatan membaca massal lainnya secara periodik. Kedua, terbentuknya komunitas siswa membaca melalui kegiatan WJLRC. Hal ini tampak dari: 1) meningkatnya jumlah buku yang dibaca dan dibuat reviunya oleh siswa; 2) meningkatnya kecepatan membaca siswa peserta kegiatan WJLRC; 3) adanya kesinambungan dan keberlanjutan kegiatan WJLRC antar kelas. Ketiga, publikasi tulisan karya literasi siswa dan guru. Hal ini tampak dari adanya bukti aktivitas dan karya literasi siswa serta guru pada website WJLRC. Keempat, meningkatnya dukungan orang tua dan masyarakat terhadap gerakan literasi sekolah. Hal ini tampak dari: 1) adanya keterlibatan langsung orang tua dan 
masyarakat dalam berbagai kegiatan gerakan literasi sekolah; 2) meningkatnya dukungan dan kepedulian orang tua dan masyarakat terhadap upaya penumbuhan budaya baca di rumah dan lingkungan masyarakat; 3) adanya donasi buku untuk sekolah dari orang tua dan masyarakat.

\section{DAFTAR PUSTAKA}

Creswell, J.W. 1994. Research Design Qualitative and Qualitative Approach. London: Publication.

Departemen Pendidikan dan Kebudayaan. 2016. Panduan Gerakan Literasi Sekolah di Sekolah Menengah Pertama. Jakarta: Kemdikbud.

Departemen Pendidikan dan Kebudayaan. 2016. Desain Induk Gerakan Literasi sekolah. Jakarta: Kemdikbud.

Dinas Pendidikan Propinsi Jawa Barat. 2017. Gerakan Literasi Sekolah Melalui Program WJLRC

Dinas Pendidikan Propinsi Jawa barat 2016. Panduan Gerakan Literasi Sekolah Melalui West Java Leader's Reading Challenge (WJLRC). Bandung: Disdik Prop. Jabar.

Jamarudin. 2014. Pengawas Sekolah Dilatih Memantau Kemajuan Literasi Sekolah. [on line].From:http://beritamusi.co.id/2016/05/25/pengawas-sekolah-dilatihmemantau- kemajuan-literasi-sekolah/

Moleong, LJ. 2007. Metode Penelitian Kualitatif. Bandung: Rosda Karya.

Nurohman, A. 2014. Signifikansi Literasi Informasi (information Literacy) Dalam Dunia Pendidikan Di Era Global. Purwokerto: STAIN Purwokerto Jurnal Kependidikan, Vol. II No. 1 Mei 2014

Sugiono. 2013. Metode Penelitian Administrasi. Bandung: Alfabeta

Supiandi. 2016. Menumbubkan Budaya Literasi di Sekolah dengan Program Kata. Jakarta: Kemdikbud 